\title{
Combined diurnal variations of discharge and hydrochemistry of the Isunnguata Sermia outlet, Greenland Ice Sheet
}

\author{
Joseph Graly, Joel Harrington, and Neil Humphrey \\ Department of Geology and Geophysics, University of Wyoming, 1000 E. University Ave. Laramie, WY 82071, USA \\ Correspondence to: Joseph Graly (jgraly@iupui.edu)
}

Received: 1 June 2016 - Discussion started: 12 July 2016

Revised: 13 February 2017 - Accepted: 21 March 2017 - Published: 5 May 2017

\begin{abstract}
In order to examine daily cycles in meltwater routing and storage in the Isunnguata Sermia outlet of the Greenland Ice Sheet, variations in outlet stream discharge and in major element hydrochemistry were assessed over a 6-day period in July 2013. Over 4 days, discharge was assessed from hourly photography of the outlet from multiple vantages, including where midstream naled ice provided a natural gauge. $\mathrm{pH}$, electrical conductivity, suspended sediment, and major element and anion chemistry were measured in samples of stream water collected every $3 \mathrm{~h}$.

Photography and stream observations reveal that although river width and stage have only slight diurnal variation, there are large diurnal changes in discharge shown by the doubling in width of what we term the "active channel", which is characterized by large standing waves and fast flow. The concentration of dissolved solutes follows a sinusoidal diurnal cycle, except for large and variable increases in dissolved solutes during the stream's waning flow. Solute concentrations vary by $\sim 30 \%$ between diurnal minima and maxima. Discharge maxima and minima lag temperature and surface melt by $3-7 \mathrm{~h}$; diurnal solute concentration minima and maxima lag discharge by 3-6h.

This phase shift between discharge and solute concentration suggests that during high flow, water is either encountering more rock material or is stored in longer contact with rock material. We suggest that expansion of a distributed subglacial hydrologic network into seldom accessed regions during high flow could account for these phenomena, and for a spike of partial silicate reaction products during waning flow, which itself suggests a pressure threshold-triggered release of stored water.
\end{abstract}

\section{Introduction}

Dissolved load in glacial outlet streams has long been employed as a metric for assessing water-rock interactions occurring beneath glaciers and ice sheets. Glacierized basins have comparable dissolved loads to non-glacial rivers, but are enriched in mobile cations and depleted in $\mathrm{Si}$ (Anderson et al., 1997). The chemistry of glacial water typically suggests that observed solute concentrations are reached due to the presence of reactive accessory minerals and fresh mineral surfaces in glacial sediments (Drever and Hurcomb, 1986). Dissolved load is therefore linked to physical erosion in subglacial environments (Anderson, 2005). Dissolved load is also indicative of the degree to which atmospheric gases have been sequestered by chemical processes in the subglacial environment (Hodson et al., 2000).

Diurnal variation of solute concentration is a potential indicator of meltwater routing and storage (e.g., Brown, 2002). Solute concentration is controlled by total water-rock contact over the water residence time in the subglacial environment and by the reactivity of minerals contacted by the water. In particular, two end member cases are expected: if dilution produces an inverse relationship between discharge and solute concentration, minimal changes in water-rock interaction over time are suggested, whereas if increased discharge is coupled to increased solute concentration, diurnal changes in the processes of water-rock interaction or storage are suggested.

Several studies of small alpine glaciers have found solute concentration and discharge to vary inversely, with rising discharges corresponding to falling concentrations of dissolved solutes (e.g., Collins, 1995; Hindshaw et al., 2011; Tranter et al., 1993; Tranter and Raiswell, 1991). Ions produced by saturation-limited reactions, such as calcite dissolution, 
can show increased load with discharge, but typically with diminished concentration per water volume (Mitchell and Brown, 2007). Elements that are limited by factors such as the rate of sorption/desorption will have constant flux levels and will only be diluted by increased water flow (Mitchell and Brown, 2007). Consequently, correlations between discharge and dissolved load are typically weak (Collins and MacDonald, 2004). These dilution relationships have been attributed to the dominance of channelized flow in alpine environments. In cases for which subglacial water is confined to fixed conduits, increased water flow will expand the size of the conduits and increase the speed of throughflow but will have a minimal impact on the area of water-bed contact (Nye, 1976; Röthlisberger, 1972).

Larger glacial systems have more complex water-rock interactions (e.g., Wadham et al., 2010), and have frequently demonstrated more complex hysteresis in the relationship between discharge and solute concentration. At the outlet of a large glacierized basin in SE Alaska, increases in dissolved load lag spikes in discharge by several days (Anderson et al., 2003). Anderson and others attribute this to storage of water in a distributed system only released during the waning stages of flow. In distributed or linked-cavity flow, increased discharge allows flowing water to spread out across the glacier's bed and thereby increase the area of water-bed contact (Humphrey, 1987; Kamb, 1987). Time series data from the Watson River, near Kangerlussuaq, West Greenland, show out-of-phase variation in discharge and solute concentration, with maximum daily solute concentrations occurring on the rising limb of the discharge hydrograph (Yde et al., 2014). However, on the scale of the melt season as a whole, Yde and others find a strong inverse correlation between discharge and solute concentration, which they attribute to conduits carrying a substantially higher portion of the meltwater flow than the distributed subglacial system. Lags between minimum discharge and peak solute concentrations have also been observed in karst dominated systems, such as Tsanfleuron, Swiss Alps, where flux from groundwater is hydrologically important (Zeng et al., 2012). Such lags are also observed in non-glacial streams and have long been understood to result from the mixing of groundwater, soil water, and surface runoff - each having a unique response time to rainfall events (e.g., Evans and Davies, 1998). The existence of a range of distributed and channelized flow mechanisms under larger ice bodies similarly suggests a range of response times to input from surface melt water.

Seven measurements of dissolved solute chemistry taken from samples collected over the course of 2 days in 2011 at the terminus of Insunnguata Sermia, a major landterminating West Greenland outlet glacier, potentially show a direct relationship between solute concentration and discharge (Graly et al., 2014; Landowski, 2012). In this limited time series, solute concentration appears to peak at midafternoon, while discharge is high, and minimal in the early morning hours, with total variation of $<20 \%$. To investigate fur-

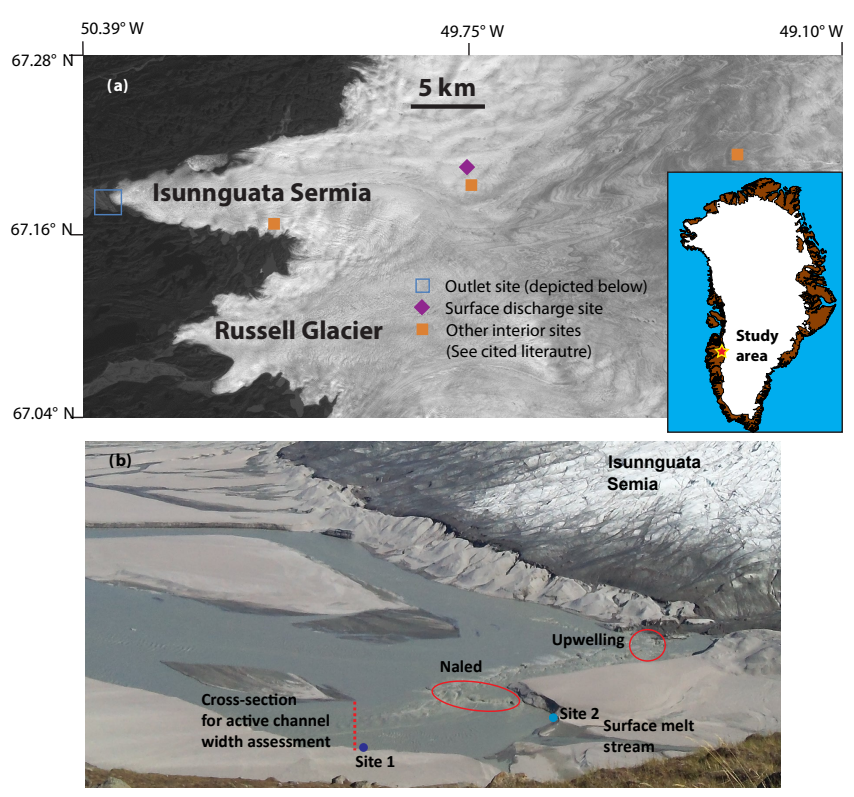

Figure 1. (a) Location of the study area on satellite imagery provided by polar geospatial data center. (b) Overhead photograph of the study area taken 21 July 2013 on an overlooking ridge, $400 \mathrm{~m}$ above and $900 \mathrm{~m}$ away from the stream. Important sampling and observational features are labeled. Samples were collected at site 1 from 10:00 on 16 July 2013 to 11:00 on 18 July 2013. Samples were collected at site 2 from 14:00 h on 18 July 2013 to 20:00 on 21 July 2013. Beginning at 10:00 on 18 July 2013 , hourly photographs on the labeled naled and $\sim 100 \mathrm{~m}$ cross section were taken.

ther whether a direct relationship exists between discharge and solute concentration, we returned to the same site for a 6-day period of the summer of 2013, collecting eight samples per day for chemical analysis.

\section{Field site}

Water samples were collected from the terminus of the Isunnguata Sermia outlet of the Greenland Ice Sheet (Fig. 1). The outlet glacier occupies a deeply cut glacial valley, with surrounding hilltops $>400 \mathrm{~m}$ above sea level. Deep, glaciallycarved trenches continue under the ice sheet for more than $20 \mathrm{~km}$ into the interior, where ice depths reach $>1000 \mathrm{~m}$ (Jezek et al., 2013). The Isunnugata Sermia outlet has a catchment that encompasses $>2400 \mathrm{~km}^{2}$ of the ablation zone, making it one of the largest subglacial drainage basins in western Greenland (Palmer et al., 2011). The regional geology consists primarily of Paleoproterozoic gneisses and granitoids (van Gool et al., 2002), providing a silicate bedrock substrate for subglacial chemistry.

Water emerges from a single location on the south side of Isunnguata Sermia's terminus front $\sim 30 \mathrm{~m}$ above sealevel (Fig. 1) and traverses a broad, $>100 \mathrm{~km}$ long sandur to the fjord. Discharge of pressurized subglacial water creates a large upwelling capable of expelling water multiple 
meters into the air and, although no fully quantitative measurement could be made, peak discharge was estimated in the hundreds of $\mathrm{m}^{3} \mathrm{~s}^{-1}$, as is consistent with typical summer discharge in the nearby Watson River (Hasholt et al., 2013). Ice-cored moraines and frozen outwash shape the course of outlet waters. On the sandur, frozen outwash channels the water into a single thread, although the large sediment load creates rapidly changing channel and bed geometry. Near the terminus, the frozen outwash of the sandur is elevated $\sim 2$ $4 \mathrm{~m}$ above the discharging stream. The main stream is also fed by minor ice surface melt streams. A small stream that runs along the south lateral margin of the glacier joins the main terminal outlet stream just below the primary upwelling site.

This work was performed as part of a wider program of coordinated studies of the Isunnguata Sermia terminus region. Hot water boreholes along a transect from the outlet to $40 \mathrm{~km}$ upstream have provided data regarding water pressure (Meierbachtol et al., 2013), ice temperature (Harrington et al., 2015), subglacial water chemistry (Graly et al., 2014), and mass balance between subglacial sediment and rock (Graly et al., 2016). More limited data sets from Isunnguata Sermia's terminal and lateral outlets were reported for the 2010, 2011, and 2012 seasons (Graly et al., 2014). The work reported here is based on samples and data collected over a 6-day period from 16 to 21 July 2013.

\section{Methods}

\subsection{Discharge}

Discharge measurements of the outlet were difficult to obtain. There is no exposed bedrock near the stream to act either as an elevation reference or to stabilize the river bed. Obtaining accurate cross profiles of the stream was prohibitively dangerous, with high flows, collapsing banks, and a considerable flux of mobile ice blocks. Attempts to install a stage pole were frustrated by considerable stage variation over time associated with cutting and filling of the stream bed. Once the stream opens out from its restriction by remnant glacier ice near the upwelling, stage is poorly correlated with discharge. The stream instead scours sediment during the rising limb and deposits it on the trailing limb of the daily hydrograph. It was decided that only relative discharge should be assessed. This was aided by repeat photography from two fixed locations.

Hourly stream photography began at 10:00 on 18 July and continuing through 20:00 on 21 July. From one vantage point, the central upwelling of subglacial water was photographed from the south, as it poured out from around the moraine. This vantage captured a $\sim 1 \mathrm{~m}$-high, mid-channel naled formed from freezing of outlet waters during winter months. The naled was variably covered or exposed as discharge varied and acted as a stream gauge in this respect.
This portion of the stream is restricted by frozen sediment and stream height is controlled by discharge.

A second vantage, from a rise above the south bank, captured a $\sim 200 \mathrm{~m}$ long stretch of the outlet stream. In this portion of the stream, increased discharge caused scour and expansion of the stream's active channel. Photography allowed for an assessment of relative active channel width. Large waves and faster velocities are confined to this active channel. The distance between the upstream end of a persistent, midstream point bar and a distinct feature on the south shore was measured on each photograph (Fig. 1). The length of the portion of this transect characterized by large waves and flow features was also measured, allowing for the calculation of the fraction of the stream width contained by the active channel. On most of the photographs, the break between the large standing waves and the surrounding quiescent flow was unambiguous. The second vantage also allowed for an assessment of flow state and Froude number from the presence of features such as standing waves.

During the first 2 days of the sampling period, stream surface velocity was measured by having a person repeatedly run in pace with the movement of the stream surface along a $100 \mathrm{~m}$ stretch of the sandur. This was accomplished by observing visually consistent mobile features of the stream, such as lineations within waveforms and small pieces of floating ice. Measurements were taken during morning, afternoon, and evening stages to assess variation in velocity associated with high and low flow. During this earlier period, changes in the width of the active channel and volume of the water pouring over the naled were also observed (though without systematic photography from a consistent vantage).

\subsection{Interior surface melt}

In order to compare variation in terminus discharge to melt in the surface interior, we also consider discharge measurements from an interior ice sheet surface stream. The stream was gauged during June of 2012, so the data are not directly comparable to the measurements collected in 2013. However inasmuch as interior melt is primarily controlled by insolation, the stream's variation likely represents a typical pattern for the timing and scaling of diurnal summer surface melt fluctuations. Coincidentally, the progression of the Greenland Ice Sheet melt season was fairly comparable between June 2012 and July 2013, with ablation rates of 6$10 \mathrm{Gt} \mathrm{day}^{-1}$ during both periods (Langen et al., 2013). The supraglacial stream was gauged during a period in which bare ice was melting, so water retention in snow did not affect its hydrology.

The surface stream was located at $67.2^{\circ} \mathrm{N}$ and $49.8^{\circ} \mathrm{E}$, $\sim 25 \mathrm{~km}$ from the terminal outlet. Stream height was gauged with a calibrated pole drilled into ice. Surface velocity was measured by timing floating ice along a course of known distance. Cross-sectional area was directly measured in the region where the gauge was emplaced and calibrated to gauge 
height. Transect slope was measured by pole and automatic level. Six measurements of surface velocity were used to calculate an average Manning coefficient from the measured slope and hydraulic radius of the stream. Discharge was then calculated from change in gauge height. Stage height was measured every half hour or hour for a period from 11:30 on 18 June 2012 to 20:00 on 21 June 2012. During 18, 19, and 20 June, sunny weather predominated; 21 June had rainy, cooler weather.

\subsection{Water sampling}

Water sampling of Isunnguata Sermia's terminal outlet began at 08:00 local time on 16 July 2013 and continued in $3 \mathrm{~h}$ increments through 20:00 on 21 July 2013. Temperatures in the interior ablation zone measured at PROMICE KAN_M weather station stayed at $\sim 0.5$ positive degrees per day over 16-18 July and steadily rose to 1.3 positive degrees per day over 19-21 July. Samples were collected by lowering a liter Nalgene polypropylene bottle attached to an adjustable-length pole into discharging waters within $400 \mathrm{~m}$ of the subglacial upwelling. The bottle was dipped and rinsed in flowing stream water prior to final sample collection. Samples were initially collected from the south bank of the outlet stream, from the banks at the beginning of the outwash plain (Fig. 1; Site 1). During 17 July, the main course of the river shifted so that location had diminished flow and an emerging bank channeled waters from the lateral side stream to the location. Commencing at 14:00 on 18 July, sampling was relocated above the lateral side stream on the banks of the terminal moraine (Fig. 1; Site 2). The sampling location was not subsequently changed. Excepting periods in which the emerging bank channeled lateral stream water to the first location, both locations sampled water from the main subglacial outlet and should produce comparable results.

Upon collection, $125 \mathrm{~mL}$ of each water sample were pumped through $0.1 \mu \mathrm{m}$ nylon filters, with filtered water and filter papers saved for laboratory analyses. A colorimetric alkalinity test, a conductivity measurement, and a pH measurement were performed on the remaining unfiltered sample. Alkalinity tests were performed with a Hach Model AL-AP alkalinity test kit. Results of field alkalinity tests were only accurate to $25 \mu \mathrm{M}$. Alkalinity was therefore also calculated by charge balance from the other measured ions. $\mathrm{pH}$ measurements and conductivity measurements were performed with Beckman-Coulter $\Phi 460$ multi-parameter meter. $\mathrm{pH}$ was measured using a low ionic strength probe, with a three-point calibration employed daily.

Subsequent water analyses were performed in the University of Wyoming Aqueous Geochemistry Lab. Concentrations of $\mathrm{Si}, \mathrm{Ca}, \mathrm{Mg}, \mathrm{Na}$, and $\mathrm{K}$ were measured on a Perkin Elmer Elan 6000 inductively coupled plasma quadrupole mass spectrometer (ICP-MS). Concentrations of $\mathrm{SO}_{4}^{2-}, \mathrm{Cl}^{-}$, $\mathrm{NO}_{3}^{-}$, and $\mathrm{Fl}^{-}$were measured on a Dionex ICS 500 ion chromatograph. Element and ion analyses were measured to- (a)

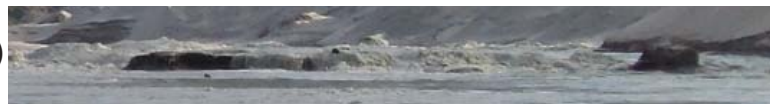

(b)

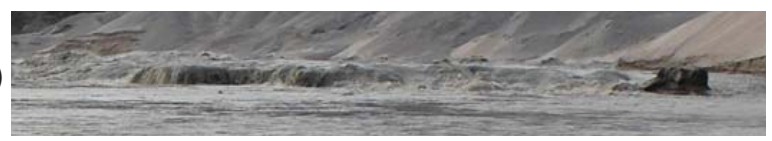

(c)

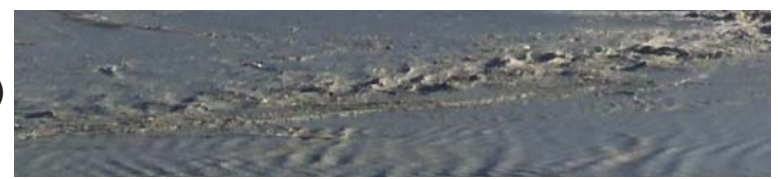

(d)

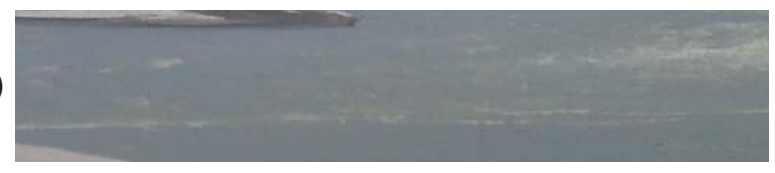

(e)

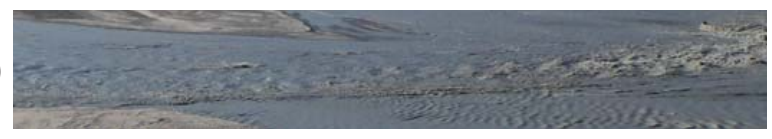

(f)

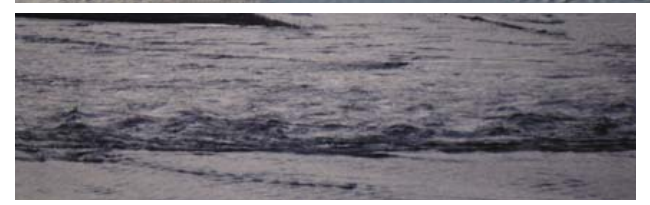

Figure 2. Photographs of typical flow patterns in the Isunnguata Sermia outlet. (a) Midstream naled exposed at during low flow (08:00). (b) Midstream naled covered during high flow (21:00). Panels (c)-(f) show images of flow captures from the overhead vantage during low (08:00), waxing (14:00), high (21:00) and waning (00:00) stages. Waxing and waning stages show different wave morphology but maintain standing wave features.

gether with procedural blanks, which were consistently measured below the lower limits of detection. The filter papers were dried overnight at $85^{\circ} \mathrm{C}$ and weighed to assess suspended load.

\section{Results}

\subsection{Discharge}

Over the 4 days during which repeat photographic observations were made, photographs of the naled show consistent minima at 08:00, with the naled mostly exposed, and a small volume of water overtopping a portion of the ice body (Fig. 2). On 18 and 19 July, the naled was completely covered by flowing water from 19:00 to 00:00. On 20 July, it was covered from 16:00, and remained covered for the remainder of the study period.

Maximum discharge is harder to determine from observations of the naled alone. Once the naled is completely covered in water, visual interpretation of maximum flow is ambiguous. Some discrimination can be made based on the height of the covered naled feature compared to the surround- 
ing waves and the angle at which the water pours over the naled (greater flows overtop the naled at a lower angle). From these features, maximum stream flow appeared to occur at 21:00 on 18 and 19 July, and 20:00 on 20 July.

Standing waves are observed at all flows (Fig. 2), although substantial differences in wave and surface morphology were noted during waxing and waning phases, with rougher water in waning flow and smoother water in waxing flow. The roughness change may represent a change in the sediment load of the river between the erosive waxing stage and the depositional waning stage. The persistence of standing waves implies near-critical-flow conditions, or a Froude number of approximately 1, for the entire study period. Measurements of stream velocity showed surface speeds of $2.86 \pm 0.12 \mathrm{~m} \mathrm{~s}^{-1}(2 \sigma, n=6)$. Variation in velocity between morning and evening stages was within measurement error. The lack of relationship between stage and discharge and velocity has been noted before in sediment-laden glacial rivers (Humphrey and Raymond, 1994).

Based on calculations from a Froude number of 1 (i.e., stream velocity squared is equal to stream depth times acceleration from gravity) and assuming a total velocity within $20 \%$ of surface velocity, stream depths of $0.5-0.9 \mathrm{~m}$ are suggested. These depth estimates were supported by observing ice blocks rolling or bouncing down the flow. The active channel's approximately constant stream velocity and persistent standing waves suggest a fairly constant stream depth. Wide areas of shallow slow water remained present during low flows and the total surface area of the stream remained approximately constant. Pole probing of these shallow areas suggests 10 to $20 \mathrm{~cm}$ depths. Because the active channel has an order of magnitude greater discharge per transect meter than the stream's marginal areas, we infer that the crosssectional area of the active channel is the primary control on discharge. Rising discharge is accommodated by scouring on the margins of the active channel; falling discharge is accommodated by deposition.

Assessment of the active channel width from repeated photography shows substantial differences between morning hours $(\sim 05: 00-10: 00)$, where $20-30 \%$ of the stream is comprised of active channel characteristics, and late afternoon/evening hours ( 18:00-00:00) when $>40 \%$ of the stream is comprised of active channel characteristics. These observations are generally consistent with assessments of the height of water pouring over the naled (Fig. 3). Though repeated photography from a consistent vantage was not performed during the first 2 days of the study, field observations and photographs from that period show similar changes in the active channel width and naled overflow.

\subsection{Interior surface stream}

The calculated Manning coefficient for the interior stream was $0.0117 \pm 0.0018(2 \sigma)$. Its discharge varied by as much as an order of magnitude during the course of diurnal cy-
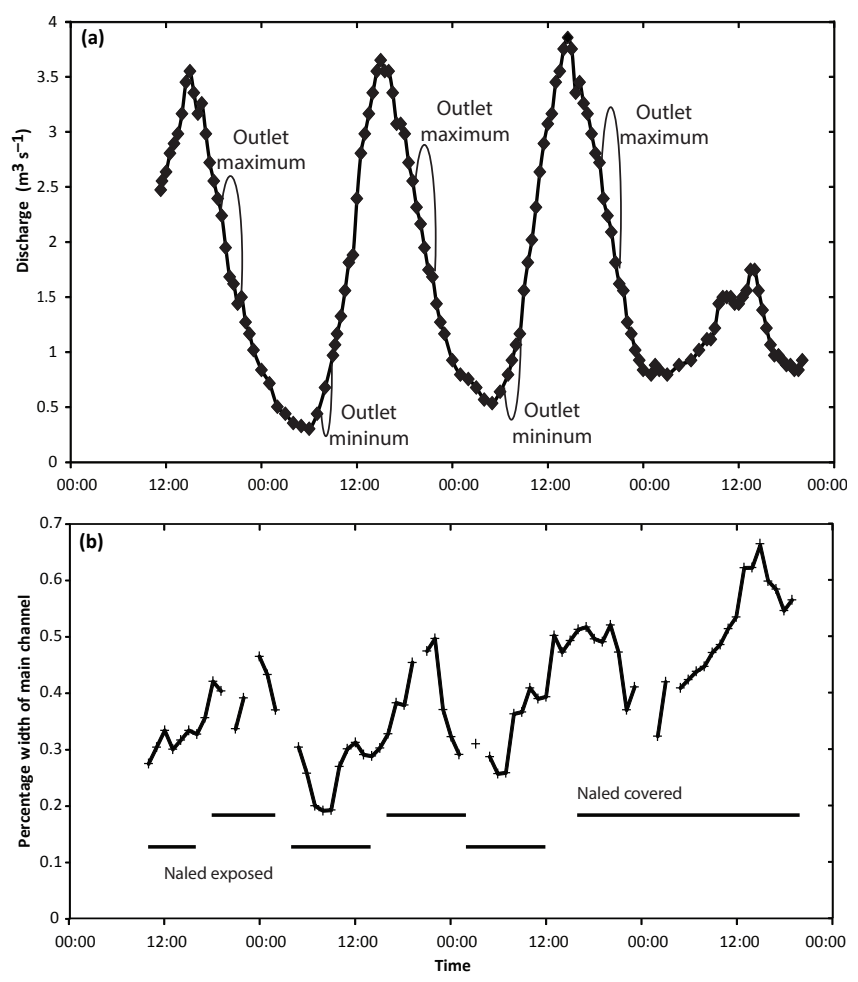

Figure 3. (a) Measured discharge in an interior surface stream over a 4-day period in 2012 compared to time ranges of maximum and minimum discharge as suggested by qualitative observation of flow volumes over midstream naled ice in the outlet of Isunnguata Sermia during the study period. (b) Assessment of percentage of distance between a point bar and the shore that is characterized by large waves suggestive of deep, fast flow. Periods of time in which the midstream naled is exposed and covered are included for comparison.

cles, with low values as small as $0.3 \mathrm{~m}^{3} \mathrm{~s}^{-1}$ and high values greater than $3.5 \mathrm{~m}^{3} \mathrm{~s}^{-1}$ (Fig. 3). Minimum stage heights consistently occurred around 04:00. Maximum stage heights consistently occurred at 14:00 or 15:00. These data contrast with our observations of water pouring over the naled. The naled minimum occurred approximately $4 \mathrm{~h}$ later than minimum of surface melt. The naled maximum occurred approximately $6 \mathrm{~h}$ later than maximum surface melt. This delay is representative of the integration of the travel time delays from the entire glacier catchment.

\subsection{Water analyses}

The sampled waters were generally chemically dilute, with $292 \pm 50$ micromoles per liter dissolved solutes (Table 1). $\mathrm{Ca}$ was the dominant cation, followed by $\mathrm{Na}, \mathrm{K}$, and $\mathrm{Mg}$ (Fig. 4). Mg abundances were an order of magnitude lower than the other major cations. Dissolved Si occurred at comparable abundance to Na. Standard deviations of the mass spectrometer measurements were $<1 \%$ of the measured value. Bicarbonate (measured as alkalinity) was the dominant an- 
Table 1. Field and laboratory measurements (results in micromolarity unless otherwise noted).

\begin{tabular}{|c|c|c|c|c|c|c|c|c|c|c|c|c|c|c|c|}
\hline Sample & Date and time & $\mathrm{pH}$ & $\begin{array}{r}\text { Electrical } \\
\text { conductivity } \\
(\mu \mathrm{S})\end{array}$ & $\begin{array}{r}\text { Suspended } \\
\text { sediment } \\
\left(\mathrm{gl}^{-1}\right)\end{array}$ & $\begin{array}{r}\text { Field } \\
\text { alkalinity }\end{array}$ & $\begin{array}{r}\text { Calculated } \\
\text { alkalinity }\end{array}$ & $\mathrm{Ca}$ & $\mathrm{K}$ & $\mathrm{Mg}$ & $\mathrm{Na}$ & $\mathrm{Si}$ & $\mathrm{Fl}^{-}$ & $\mathrm{Cl}^{-}$ & $\mathrm{NO}_{3}^{-}$ & $\mathrm{SO}_{4}^{2-}$ \\
\hline GL13-1 & $16720138: 10$ & 8.6 & 9.7 & 1.84 & 150 & 141.2 & 63.1 & 23.2 & 6.4 & 38.1 & 38.7 & 0.7 & 18.2 & 0.8 & 19.7 \\
\hline GL13-2 & $167201311: 00$ & 8.8 & 11.0 & 1.92 & 175 & 146.5 & 66.0 & 25.7 & 6.3 & 38.8 & 44.7 & 2.9 & 16.7 & 0.8 & 21.2 \\
\hline GL13-3 & $167201314: 00$ & 8.7 & 11.5 & NA & 150 & 133.9 & 61.9 & 23.1 & 6.4 & 40.2 & 33.0 & 0.7 & 20.6 & 1.4 & 21.7 \\
\hline GL13-4 & $167201317: 00$ & 8.7 & 9.4 & NA & 150 & 128.8 & 56.3 & 21.6 & 6.9 & 33.5 & 27.3 & 0.7 & 14.7 & 0.8 & 18.3 \\
\hline GL13-5 & $167201320: 00$ & 8.7 & 10.0 & 3.28 & 150 & 114.8 & 50.3 & 15.6 & 4.9 & 28.6 & 27.8 & 0.6 & 7.5 & 0.5 & 15.6 \\
\hline GL13-6 & $167201323: 00$ & 8.8 & 11.2 & 2.24 & 150 & 129.1 & 55.1 & 24.3 & 5.6 & 40.9 & 33.8 & 0.7 & 23.4 & 1.7 & 15.9 \\
\hline GL13-7 & $17720132: 00$ & 8.7 & 8.8 & 2.80 & 150 & 124.0 & 56.0 & 18.8 & 5.5 & 29.7 & 33.0 & 0.6 & 11.5 & $<0.5$ & 17.6 \\
\hline GL13-8 & 1772013 5:00 & 8.8 & 10.3 & 1.60 & 175 & 135.9 & 59.7 & 27.0 & 5.9 & 38.9 & 34.3 & $<0.4$ & 22.6 & $<0.5$ & 19.4 \\
\hline GL13-9 & 1772013 8:00 & 8.9 & 13.0 & 2.64 & 200 & 160.1 & 77.1 & 24.7 & 6.8 & 42.1 & 38.9 & 0.7 & 22.3 & 3.9 & 23.8 \\
\hline GL13-10 & $177201311: 00$ & 8.5 & 12.7 & 2.40 & 150 & 127.4 & 61.8 & 22.1 & 6.5 & 33.6 & 34.5 & 0.7 & 15.2 & 1.2 & 23.8 \\
\hline GL13-11 & $177201314: 00$ & 8.0 & 7.3 & 1.04 & 100 & 60.7 & 31.9 & 9.6 & 4.7 & 16.0 & 23.3 & 0.5 & 6.6 & $<0.5$ & 15.6 \\
\hline GL13-13 & 1772013 17:00 & 8.3 & 6.5 & 1.68 & 100 & 75.3 & 36.0 & 15.1 & 4.4 & 20.1 & 23.1 & 0.5 & 11.9 & $<0.5$ & 14.1 \\
\hline GL13-14 & $177201320: 00$ & 8.6 & 8.2 & 1.36 & 100 & 82.4 & 38.7 & 15.4 & 4.8 & 19.2 & 25.9 & 0.4 & 8.8 & $<0.5$ & 15.0 \\
\hline GL13-15 & $177201323: 00$ & 8.8 & 9.1 & 3.52 & 150 & 129.4 & 51.2 & 19.2 & 5.1 & 31.5 & 29.7 & 1.3 & 13.5 & $<0.5$ & 9.5 \\
\hline GL13-16 & $18720132: 00$ & 8.7 & 8.0 & 3.20 & 150 & 124.0 & 52.5 & 20.3 & 5.2 & 31.4 & 29.9 & 0.7 & 12.5 & 0.9 & 14.6 \\
\hline GL13-17 & $18720135: 00$ & 8.5 & 10.7 & 2.88 & 150 & 131.3 & 58.2 & 21.7 & 6.1 & 32.7 & 33.8 & 0.9 & 14.6 & 0.8 & 17.7 \\
\hline GL13-18 & 1872013 8:00 & 8.9 & 12.7 & 3.52 & 150 & 132.2 & 58.3 & 26.5 & 5.8 & 33.7 & 33.5 & 0.9 & 12.6 & $<0.5$ & 21.5 \\
\hline GL13-19 & 1872013 11:00 & 8.5 & 9.8 & 2.56 & 150 & 104.8 & 50.3 & 21.5 & 5.8 & 30.1 & 30.9 & 0.7 & 18.4 & $<0.5$ & 20.0 \\
\hline GL13-20 & $187201314: 00$ & 8.5 & 11.0 & 3.60 & 175 & 127.9 & 56.0 & 26.3 & 5.5 & 32.8 & 30.8 & 2.0 & 14.2 & 0.8 & 18.6 \\
\hline GL13-21 & $187201317: 00$ & 8.7 & 9.4 & 3.60 & 150 & 112.8 & 48.9 & 22.9 & 4.7 & 30.1 & 28.1 & 0.6 & 13.8 & 0.7 & 16.2 \\
\hline GL13-22 & $187201320: 00$ & 8.6 & 7.6 & 4.00 & 125 & 106.6 & 45.9 & 20.2 & 4.4 & 29.8 & 27.2 & 0.6 & 15.0 & 1.0 & 13.7 \\
\hline GL13-23 & $187201323: 00$ & 8.6 & 7.1 & 3.20 & 100 & 90.4 & 44.9 & 19.5 & 4.4 & 33.3 & 26.0 & 0.5 & 34.9 & 0.6 & 12.5 \\
\hline GL13-24 & $19720132: 00$ & 8.7 & 14.5 & 3.84 & 125 & 119.5 & 58.1 & 23.1 & 5.0 & 30.8 & 32.6 & 0.7 & 29.4 & 1.1 & 14.6 \\
\hline GL13-25 & 1972013 5:00 & 8.3 & 9.4 & 2.56 & 150 & 123.8 & 50.3 & 23.6 & 4.8 & 28.4 & 30.2 & $<0.4$ & 8.5 & $<0.5$ & 15.0 \\
\hline GL13-26 & 1972013 8:00 & 8.6 & 10.2 & 2.80 & 150 & 125.8 & 56.1 & 27.1 & 4.9 & 38.4 & 28.6 & 0.8 & 24.9 & 1.3 & 17.4 \\
\hline GL13-27 & $197201311: 00$ & 8.7 & 10.5 & 2.64 & 150 & 129.9 & 59.2 & 28.3 & 5.3 & 35.1 & 30.4 & 0.8 & 18.6 & 2.1 & 20.5 \\
\hline GL13-28 & $197201314: 00$ & 8.5 & 11.9 & 2.24 & 150 & 119.1 & 52.0 & 23.1 & 4.8 & 31.0 & 28.3 & 0.7 & 8.7 & 1.1 & 19.1 \\
\hline GL13-29 & $197201317: 00$ & 8.4 & 11.7 & 3.44 & 125 & 116.9 & 51.3 & 25.0 & 4.7 & 31.0 & 26.1 & 0.7 & 16.4 & 1.5 & 16.3 \\
\hline GL13-30 & $197201320: 00$ & 8.6 & 7.7 & 3.84 & 100 & 106.8 & 45.0 & 23.9 & 4.3 & 29.6 & 24.8 & 0.7 & 15.1 & 1.2 & 14.2 \\
\hline GL13-31 & $197201323: 00$ & 8.6 & 7.4 & 2.96 & 100 & 104.7 & 42.7 & 24.5 & 4.0 & 29.3 & 23.9 & 0.6 & 14.6 & 0.8 & 13.3 \\
\hline GL13-32 & 2072013 2:00 & 8.5 & 15.5 & 3.12 & 200 & 204.6 & 64.6 & 42.3 & 6.2 & 71.0 & 27.8 & 0.6 & 6.6 & 8.5 & 17.2 \\
\hline GL13-33 & 2072013 5:00 & 8.0 & 8.6 & 3.68 & 150 & 129.8 & 55.7 & 24.5 & 4.8 & 30.5 & 26.8 & 0.7 & 10.1 & 1.8 & 16.9 \\
\hline GL13-34 & 2072013 8:00 & 8.4 & 9.7 & 3.20 & 150 & 124.1 & 54.2 & 22.6 & 5.0 & 33.4 & 28.5 & 0.8 & 8.5 & $<0.5$ & 20.5 \\
\hline GL13-35 & $207201311: 00$ & 8.3 & 11.5 & 2.16 & 150 & 127.0 & 55.0 & 28.4 & 5.0 & 33.3 & 29.6 & 0.8 & 8.9 & 1.3 & 21.8 \\
\hline GL13-36 & $207201314: 00$ & 8.4 & 9.9 & 2.88 & 150 & 117.9 & 51.9 & 24.1 & 4.8 & 32.5 & 28.5 & 0.8 & 8.7 & 1.3 & 20.7 \\
\hline GL13-37 & $207201317: 00$ & 8.5 & 10.0 & 1.84 & 150 & 111.8 & 48.2 & 22.3 & 4.6 & 31.3 & 27.6 & 1.3 & 10.9 & 1.2 & 17.0 \\
\hline GL13-38 & $207201320: 00$ & 8.7 & 9.1 & 2.00 & 125 & 102.8 & 42.1 & 18.1 & 4.1 & 29.1 & 24.6 & 0.7 & 7.4 & $<0.5$ & 14.4 \\
\hline GL13-39 & $207201323: 00$ & 8.1 & 6.6 & 1.44 & 100 & 81.6 & 42.1 & 12.6 & 5.5 & 22.8 & 29.4 & $<0.4$ & 10.5 & $<0.5$ & 19.2 \\
\hline GL13-40 & 2172013 2:00 & 8.8 & 7.7 & 1.36 & 150 & 127.8 & 48.7 & 25.0 & 4.8 & 41.0 & 28.6 & 0.8 & 12.3 & 1.3 & 15.4 \\
\hline GL13-41 & 2172013 5:00 & 8.2 & 7.2 & 3.68 & 150 & 110.5 & 45.8 & 21.1 & 4.5 & 34.1 & 25.9 & 0.7 & 12.1 & 1.2 & 15.6 \\
\hline GL13-42 & 2172013 8:00 & 8.7 & 8.2 & 3.68 & 150 & 110.0 & 47.6 & 18.8 & 4.5 & 31.8 & 27.0 & 0.7 & 8.6 & 1.3 & 17.0 \\
\hline GL13-43 & $217201311: 00$ & 8.4 & 8.8 & 2.72 & 150 & 112.0 & 46.9 & 20.9 & 4.5 & 33.3 & 26.8 & 0.8 & 8.3 & 0.7 & 17.6 \\
\hline GL13-44 & $217201314: 00$ & 8.1 & 10.2 & 3.36 & 150 & 114.6 & 47.5 & 21.5 & 4.5 & 30.7 & 26.8 & $<0.4$ & 9.0 & $<0.5$ & 16.3 \\
\hline GL13-45 & $217201317: 00$ & 8.3 & 8.1 & 2.64 & 150 & 102.7 & 44.4 & 17.1 & 4.0 & 29.6 & 24.2 & 1.0 & 10.2 & 1.4 & 14.1 \\
\hline GL13-46 & $217201320: 00$ & 8.6 & 7.4 & 3.92 & 150 & 101.7 & 40.9 & 18.3 & 4.0 & 27.8 & 24.8 & $<0.4$ & 7.7 & $<0.5$ & 13.3 \\
\hline
\end{tabular}

ion. $\mathrm{SO}_{4}^{2-}$ and $\mathrm{Cl}^{-}$are detected in all samples, but occur at a concentration that is an order of magnitude lower. Trace amounts of $\mathrm{NO}_{3}^{-}$and $\mathrm{Fl}^{-}$were detected in some samples, at values an order of magnitude below $\mathrm{SO}_{4}^{2-}$ and $\mathrm{Cl}^{-}$concentrations (Fig. 4). On average, field alkalinity measurements exceeded the alkalinity estimates from charge balance by $25 \pm 14 \mu \mathrm{M}(2 \sigma)$. Some over-measurement in the field titration is expected, as the value is recorded at the level at which the color tracer disappears (and therefore is a maximum compared to previous drop). Charge imbalance may also result from absorption of $\mathrm{H}^{+}$particles to suspended sediment in unfiltered water. Field electrical conductivity measurements showed similar results to the sum of laboratorymeasured inorganic ions ( $p<0.0001 ;$ Fig. 4$)$. Suspended sed- iment concentration did not show a consistent correlation or anti-correlation with dissolved load (Fig. 4).

The relative abundances of cation species are comparable to measurements taken at the Isunnguata Sermia terminus in the summer of 2011 (Graly et al., 2014). The $\mathrm{SO}_{4}^{2-}$ /alkalinity ratios are diminished compared to those measured in 2011, but are comparable to those found in samples collected in 2010 and 2012. The concentrations of suspended sediment are similar to those observed at nearby Leverett Glacier during the summer of 2010 (Cowton et al., 2012).

When normalized to average concentration, the magnitude and timing of cation and silica concentration variation were highly consistent between species over time (Fig. 5). Covariation of all cation and $\mathrm{Si}$ species is statistically significant 

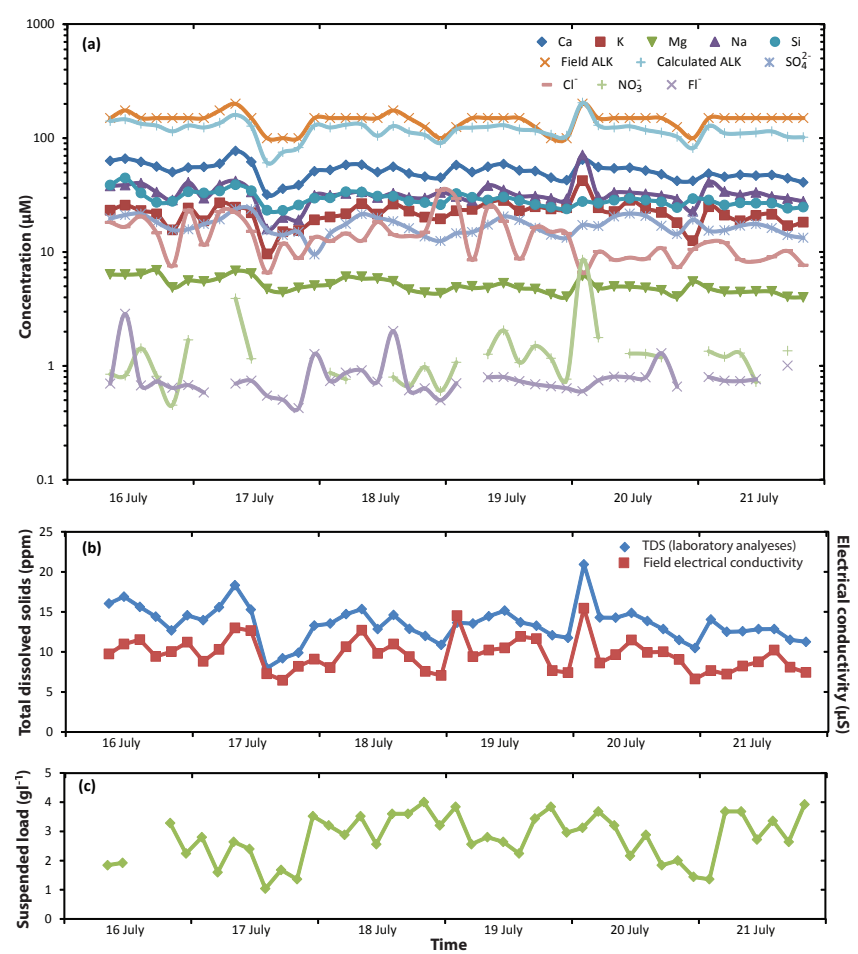

Figure 4. (a) Concentration of dissolved constituents in sampled waters over time, including laboratory measurements of cations and Si by ICP-MS, anions by ion chromatography, and field measurements of alkalinity (ALK). Alkalinity as calculated by charge balance is also depicted. (b) Total dissolved solids from the sum of the laboratory measurements and charge balance alkalinity $\left(\mathrm{HCO}_{3}\right)$ compared to field conductivity measurements. Covariation is statistically significant $(p<0.0001)$. (c) Dry weight of suspended sediment on filters.

with $p<0.05$. Covariations of $\mathrm{K}-\mathrm{Mg}, \mathrm{K}-\mathrm{Si}$, and $\mathrm{Na}-\mathrm{Si}$ have p-values ranging from 0.01 to 0.05 ; all others are $<0.0001$. All cations and silica concentrations followed a diurnal pattern, with higher concentrations present during morning and early afternoon hours and significantly lower concentrations present during later afternoon and evening hours. In several of the studied cycles, large changes in total concentration were limited to the 20:00 and 23:00 samples, which are substantially lower than the other samples collected throughout the day.

The 11:00, 14:00, 17:00, and 20:00 samples from 17 July had substantially lower solute concentrations than would be otherwise suggested by diurnal fluctuations observed elsewhere in the record. This corresponds with the period during which an emerging bank partially separated site 1 from the main channel, allowing a surface-fed side stream to dilute the water.

At 02:00 on 20 July, there was a $>60 \%$ spike in total concentration of all cations. Similar, but smaller magnitude spikes were also present during the other four measured periods of waning flow. The largest of these spikes are substan-

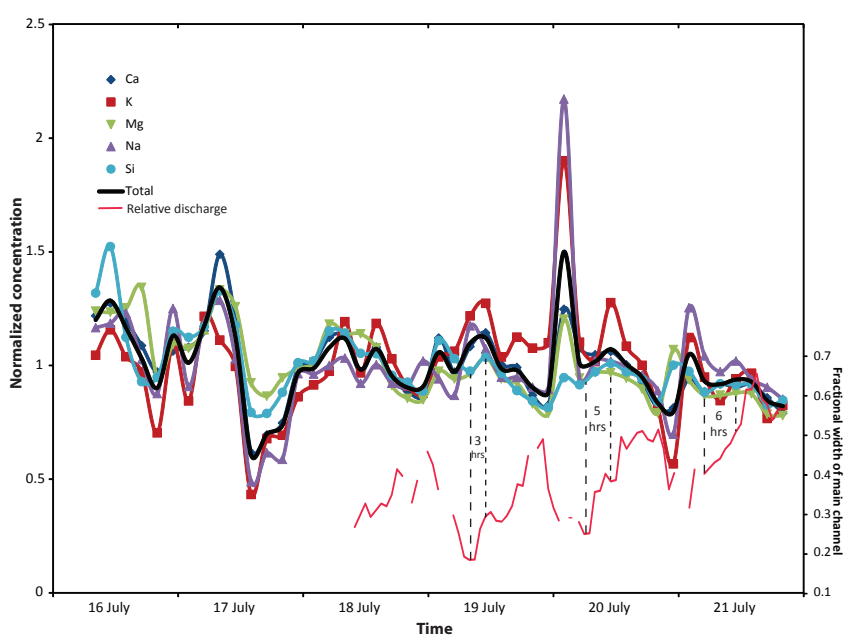

Figure 5. Concentration of dissolved cations and Si normalized to average concentration. Discharge from relative active channel width is shown for comparison. Lags between active channel width channel minima and solute concentration maxima are illustrated with dashed lines.

tially more expressed in $\mathrm{Na}$ and $\mathrm{K}$ concentrations than in $\mathrm{Ca}$, $\mathrm{Mg}$, or Si (Fig. 5). During the final measured overnight spike, elevated concentrations of $\mathrm{Mg}$ and $\mathrm{Si}$ preceded those of $\mathrm{Ca}$, $\mathrm{Na}$, and $\mathrm{K}$ by a $3 \mathrm{~h}$ measuring period. The large variability in the magnitude of these spikes suggests that the $3 \mathrm{~h}$ sampling schedule was insufficiently frequent to characterize them entirely.

Anions generally followed similar patterns, but with greater variability (Fig. 4). In particular, $\mathrm{Cl}^{-}$did not covary with other ions toward the end of the record; the 02:00 spike on 20 July coincided with a drop in $\mathrm{Cl}^{-}$concentration. $\mathrm{SO}_{4}^{2-}$ concentrations increased very minimally during the waning flow spikes, and in one case declined. During the final spike, $\mathrm{SO}_{4}^{2-}$ rose during the 11:00 period, together with $\mathrm{Mg}$ and $\mathrm{Si}$.

Excluding the spikes that occurred during waning flow, the highest concentration of dissolved solids occurred at 11:00 on 16, 19, 20, and 21 July (Fig. 5). On 17 and 18 July, the 11:00 sample was likely diluted by the side stream (which was a significant component of flow to site 1 during that period). Concentration minima were reached at 23:00 on 17 through 20 July. On 16 July, the minimum occurred in the 20:00 sample. The maximum solute concentration ranged between 22 to $49 \%$ larger than the minimum concentration, with an average daily value of $31 \pm 9 \%$.

\section{Discussion}

\subsection{Discharge and outlet stream observations}

Observations from oblique photography suggest large diurnal changes in discharge. The width of the active channel, with deeper faster water, approximately doubles in the course 
of the day (Fig. 3b). An approximate doubling of discharge is also suggested by observations of the midstream naled. The naled is of comparable scale to the depth of the stream (both order of $1 \mathrm{~m}$ ). Its exposure during low flow and burial during high flow suggests a change in stage comparable to its height. At the naled site, increased width of active channel flow is restricted by ice. Increases in flow height at the naled location are therefore approximately equivalent to increases in active channel width downstream.

During high flows, diurnal increases in discharge of up to $50 \%$ of base value are observed in the Watson River at Kangerlussuaq, where a bridge over a narrow gorge has allowed for the construction of a reliable gauge (Hasholt et al., 2013). Contrastingly, Smith et al. (2015) found minimal diurnal variation in discharge at Isunnguata Sermia terminus. However, as Smith and others estimated discharge based solely on the surface area of the outlet stream water, their analysis missed the variation in the width of the active channel and height of its flow over static features that we present. Based on our limited observational record, it appears that changes in discharge at the Isunnguata Sermia terminus are similar or larger in magnitude to those recorded at the Watson River.

\subsection{Diurnal changes in solute flux}

The lag between relative discharge minima and maximum solute concentrations is similar to other glacial and nonglacial systems where waters of differing response times are merged into a single stream. Similar lags are observed when groundwater, soil water, and surface flow mix into a stream after a rainfall event (Evans and Davies, 1998). Substantial lags between discharge and solute flux are also observed where glacial melt mixes with groundwater in a karstic system (Zeng et al., 2012) and in the mixing of marginal melt streams with a subglacial pool in a polythermic setting (Skidmore and Sharp, 1999). Even in a small alpine system, observable chemical differences between the leading and lagging limbs of the discharge hydrograph have been attributed to a mixing of englacial and subglacial waters (Tranter and Raiswell, 1991).

In the context of the Greenland Ice Sheet, periods of inphase change between discharge and solute concentration are best explained by the flushing of a linked cavity or other distributed hydrological system as hydraulic pressure rises. Seasonal changes in ice velocity in this sector of the Greenland ice sheet have been linked to a combination of distributed and channelized subglacial flow (Bartholomew et al., 2011). Dye tracing of the hydrological connections between moulins and glacial outlets has also indicated a mixture of subglacial flow regimes (Chandler et al., 2013). Though the single upwelling structure of the terminus of Isunnguata Sermia implies locally channelized flow, observations of water pressures at interior sites (Meierbachtol et al., 2013) and hydrologic theory for low ice surface slopes (Werder et al., 2013) both suggest that much of the catchment interior has a distributed flow system.

The sudden increases in solute concentration during waning flow suggest that discharge from subglacial regions with high concentrations of dissolved solutes is triggered when a threshold is reached. To our knowledge, the release of stored water during waning flow has only been previously documented on a multiday scale (Anderson et al., 2003), whereas here it occurred as part of the diurnal melt cycle. For slow-moving, distributed subglacial water to be both flushed by rising hydraulic pressures and released from storage by falling hydraulic pressures, multiple subglacial flow paths or mechanisms must be operating simultaneously.

The contrast in solute chemistry between the longwavelength increases in solute concentration (in which, all major chemical constituents respond comparably) and the waning flow spikes (in which $\mathrm{Na}, \mathrm{K}$, and alkalinity dominate) suggests differing subglacial environments and mechanisms. $\mathrm{Na}$ - and K-dominated waters likely form in settings where water-rock interactions occur only over a limited time, such that cation exchange occurs on fresh feldspar and mica surfaces, but complete silicate dissolution and clay precipitation do not occur (Blum and Stillings, 1995; Graly et al., 2014). The lack of constituents derived from reactive accessory minerals such as pyrite (i.e., $\mathrm{SO}_{4}^{2-}$ ) implies that the waters were reacting with sediment that has been depleted of accessory minerals. Such accessory mineral depletion can occur if sediment residence time in the subglacial system is sufficiently long (Graly et al., 2014). Sampling of sediment beneath ice boreholes has shown the greatest chemical depletion in portions of the ice sheet most influenced by distributed flow (Graly et al., 2016).

This variation in water chemistry suggests that the spike of chemical solutes comes from water that has temporarily entered regions of distributed flow as a part of a diurnal cycle. Modeling of subglacial water pressures suggests that near the ice sheet margin, water flows from conduits to the distributed cavity system at high conduit water pressures and back to conduits at low pressures (Meierbachtol et al., 2013). The spikes in solute concentration result from the crossing of a pressure threshold that allows water stored during high flow to suddenly enter the glacial outlet system. Solute concentration spikes might also be explained by creep closure of linked cavities that opened during high flow and expulsion of remaining solute-concentrated water. Anderson and others (2003) proposed a similar creep closure mechanism to explain increases in solute concentration during waning flow that occurred on a multiday scale in a mountain glacier setting. Following the Glen-Nye relation, the rate of creep closure of ice scales to approximately the third power of effective pressure (Cuffey and Paterson, 2010). Differences in the timing of these effects between ice sheets and mountain glaciers can therefore be explained by differences in ice thickness. 


\section{Conclusions}

A semi-quantitative relative discharge record can be constructed through hourly photographic monitoring of the static and dynamic features of a large, sediment-laden glacial outlet stream. These assessments suggest large diurnal changes in discharge over the study period at the Isunnguata Sermia outlet of the Greenland Ice Sheet (cf. Smith et al., 2015). Simultaneously collected chemical measurements show substantially smaller fluctuation in dissolved load; thus this Greenland outlet glacier does not show the discharge-driven dilution of solute concentration that is common in smaller ice masses. Periods in which dissolved solute concentrations increase and decrease along with discharge, and abrupt and variable increases in solute concentration during waning flow imply that significant contributions to the solute load are made by changes to the routing and storage of meltwater in the subglacial system over the course of the day. In particular, these results indicate considerable diurnal exchange of water between the conduit and linked cavity drainage systems, as well as implying threshold pressure conditions for these exchanges.

Data availability. The data that form the basis of the analysis appear in Table 1 of the paper.

Competing interests. The authors declare that they have no conflict of interest.

Acknowledgements. This work would not have been possible without funding from the Greenland Analogue Project (SKB, Posiva, NWMO) and NSF grant ARC-0909122. Janet Dewey assisted with laboratory analyses. Data from the Programme for Monitoring of the Greenland Ice Sheet (PROMICE) were provided by the Geological Survey of Denmark and Greenland (GEUS) at http://www.promice.dk. Thoughtful reviews by editor Rob Bingham and an anonymous referee greatly improved the manuscript.

Edited by: R. Bingham

Reviewed by: R. G. Bingham and one anonymous referee

\section{References}

Anderson, S. P.: Glaciers show direct linkage between erosion rate and chemical weathering fluxes, Geomorphology, 67, 147-157, 2005.

Anderson, S. P., Drever, J. I., and Humphrey, N. F.: Chemical weathering in glacial environments, Geology, 25, 399-402, 1997.

Anderson, S. P., Longacre, S. A., and Kraal, E. R.: Patterns of water chemistry and discharge in the glacier-fed Kennicott River, Alaska: Evidence of subglacial water storage cycles, Chem. Geol., 202, 297-312, 2003.
Bartholomew, I. D., Nienow, P., Sole, A., Mair, D., Cowton, T., King, M. A., and Palmer, S.: Seasonal variations in Greenland Ice Sheet motion: Inland extent and behaviour at higher elevations, Earth Planet. Sc. Lett., 307, 271-278, 2011.

Blum, A. E. and Stillings, L. L.: Feldspar dissolution kinetics, in: Chemical Weathering Rates of Silicate Minerals, edited by: White, A. F. and Brantley, S. L., Mineralogical Soc Amer, Chantilly, 291-351, 1995.

Brown, G. H.: Glacier meltwater hydrochemistry, Appl. Geochem., 17, 855-883, 2002.

Chandler, D. M., Wadham, J. L., Lis, G. P., Cowton, T., Sole, A., Bartholomew, I., Telling, J., Nienow, P., Bagshaw, E. B., Mair, D., Vinen, S., and Hubbard, A.: Evolution of the subglacial drainage system beneath the Greenland Ice Sheet revealed by tracers, Nat. Geosci., 6, 195-198, 2013.

Collins, D.: Dissolution kinetics, transit times through subglacial hydrological pathways and diurnal vatiations of solute content of meltwaters draining from an alpine glacier, Hydrol. Process., 9, 897-910, 1995.

Collins, D. N. and MacDonald, O. G.: Year-to-year variability of solute flux in meltwaters draining from a highly-glacierised basin, Nordic Hydrology, 35, 359-367, 2004.

Cowton, T., Nienow, P., Bartholomew, I., Sole, A., and Mair, D.: Rapid erosion beneath the Greenland ice sheet, Geology, 40, 343-346, 2012.

Cuffey, K. M. and Paterson, W. S. B.: The Physics of Glaciers, 4th Edn., Elsevier, Amsterdam, 2010.

Drever, J. I. and Hurcomb, D. R.: Neutralization of atmospheric acidity by chemical weathering in an alpine drainage basin in the North Cascade Mountains, Geology, 14, 221-224, 1986.

Evans, C. and Davies, T. D.: Causes of concentration/discharge hysteresis and its potential as a tool for analysis of episode hydrochemistry, Water Resour. Res., 34, 129-137, 1998.

Graly, J. A., Humphrey, N. F., Landowski, C. M., and Harper, J. T.: Chemical weathering under the Greenland Ice Sheet, Geology, 42, 551-554, 2014.

Graly, J. A., Humphrey, N. F., and Harper, J. T.: Chemical depletion of sediment under the Greenland Ice Sheet, Earth Surf. Proc. Land., 41, 1922-1936, 2016.

Harrington, J., Humphrey, N. F., and Harper, J. T.: Temperature distribution and thermal anomalies along a flowline of the Greenland Ice Sheet, Ann. Glaciol., 56, 98-104, 2015.

Hasholt, B., Mikkelsen, A. B., Nielsen, M. H., and Larsen, M. A. D.: Observations of runoff and sediment and dissolved loads from the Greenland Ice Sheet at Kangerlussuaq, West Greenland, 2007 to 2010, Z. Geomorphol., 57, 3-27, 2013.

Hindshaw, R. S., Tipper, E. T., Reynolds, B. C., Lemarchand, E., Wiederhold, J. G., Magnusson, J., Bernasconi, S. M., Kretzschmar, R., and Bourdon, B.: Hydrological control of stream water chemistry in a glacial catchment (Damma Glacier, Switzerland), Chem. Geol., 285, 215-230, 2011.

Hodson, A., Tranter, M., and Vatne, G.: Contemporary rate of chemical denudation and atmospheric $\mathrm{CO}_{2}$ sequestration in glacier basins: An arctic perspective, Earth Surf. Proc. Land., 25, 14471471, 2000.

Humphrey, N. F.: Coupling between water pressure and basal sliding in a linked-cavity hydraulic system, The Physical Basis of Ice Sheet Modelling, IAHS Publ. No. 170, 105-118, 1987. 
Humphrey, N. F. and Raymond, C. F.: Hydrology, erosion and sediment production in a surging glacier: Variegated Glacier, Alaska, 1982-83, J. Glaciol., 40, 539-552, 1994.

Jezek, K., Wu, X., Paden, J., and Leuschen, C.: Radar mapping of Isunnguata Sermia, Greenland, J. Glaciol., 59, 1135-1147, 2013.

Kamb, B.: Glacier surge mechansim based on linked cavity configuration of the basal water conduit system, J. Geophys. Res., 92, 9083-9100, 1987.

Landowski, C.: Geochemistry and subglacial hydrology of the West Greenland Ice Sheet, MS Thesis, Geology and Geophysics, University of Wyoming, 2012.

Langen, P. L., Ahlstrøm, A. P., Andersen, K. K., Andersen, S. B., Barletta, V., Box, J. E., Citterio, M., Colgan, W., Dybkjær, G., Fausto, R. S., Forsberg, R., Hansen, B., Hanson, S., Høyer, J. L., Sørensen, L. S., and Tonboe, R. T.: Polar Portal Season Report 2013, available at: http://polarportal.dk/en/nyheder/arkiv/ 2013-season-report/ (last access: 15 January 2017), 2013.

Meierbachtol, T., Harper, J., and Humphrey, N.: Basal drainage system response to increasing surface melt on the Greenland Ice Sheet, Science, 341, 777-779, 2013.

Mitchell, A. C. and Brown, G. H.: Diurnal hydrological - physicochemical controls and sampling methods for minor and trace elements in an Alpine glacial hydrological system, J. Hydrol., 332, 123-143, 2007.

Nye, J. F.: Water flow in glaciers: Jokulhlaups, tunnels, and veins, J. Glaciol., 17, 181-207, 1976.

Palmer, S., Shepherd, A., Nienow, P., and Joughin, I.: Seasonal speedup of the Greenland Ice Sheet linked to routing of surface water, Earth Planet. Sc. Lett., 302, 423-428, 2011.

Röthlisberger, H.: Water Pressure in Intra- and Subglacial Channels, J. Glaciol., 11, 177-203, 1972.

Skidmore, M. L. and Sharp, M. J.: Drainage system behaviour of a High-Arctic polythermal glacier, Ann. Glaciol., 28, 209-215, 1999.
Smith, L. C., Chu, V. W., Yang, K., Gleason, C. J., Pitcher, L. H., Rennermalm, A. K., Legleiter, C. J., Behar, A. E., Overstreet, B. T., Moustafa, S. E., Tedesco, M., Forster, R. R., LeWinter, A. L., Finnegan, D. C., Sheng, Y., and Balog, J.: ( Efficient meltwater drainage through supraglacial streams and rivers on the southwest Greenland ice sheet, P. Natl. Acad. Sci. USA, 112, 10011006, 2015.

Tranter, M. and Raiswell, R.: The composition of the englacial and subglacial component in bulk meltwaters draining the Gornergletscher, Switzerland, J. Glaciol., 37, 59-66, 1991.

Tranter, M., Brown, G., Raiswell, R., Sharp, M., and Gurnell, A.: A conceptual model of solute aquisition by Alpine glacial meltwaters, J. Glaciol., 39, 573-581, 1993.

van Gool, J. A. M., Connelly, J. N., Marker, M., and Mengel, F. C.: The Nagssugtoqidian Orogen of West Greenland: Tectonic evolution and regional correlations from a West Greenland perspective, Can. J. Earth Sci., 39, 665-686, 2002.

Wadham, J. L., Tranter, M., Skidmore, M., Hodson, A. J., Priscu, J., Lyons, W. B., Sharp, M., Wynn, P., and Jackson, M.: Biogeochemical weathering under ice: Size matters, Global Biogeochem. Cy., 24, GB3025, doi:10.1029/2009GB003688, 2010.

Werder, M. A., Hewit, I. J., Schoof, C. G., and Flowers, G. E.: Modeling channelized and distributed subglacial drainage in two dimensions, J. Geophys. Res.-Earth, 118, 1-19, 2013.

Yde, J. C., Knudsen, N. T., Hasholt, B., and Mikkelsen, A. B.: Meltwater chemistry and solute export from a Greenland Ice Sheet catchment, Watson River, West Greenland, J. Hydrol., 519, 2165-2179, 2014.

Zeng, C., Gremaud, V., Zeng, H., Liu, Z., and Goldscheider, N.: Temperature-driven meltwater production and hydrochemical variations at a glaciated alpine karst aquifer: implication for the atmospheric $\mathrm{CO}_{2}$ sink under global warming, Eviron. Earth Sci., 65, 2285-2297, 2012. 